Variation of natural radionuclides in non-ferrous fayalite slags during a one-month production period

Non Peer-reviewed author version

CROYMANS-PLAGHKI, Tom; Vandael Schreurs, Indy; Hult, Mikael; Marissens, Gerd; Lutter, Guillaume; Stroh, Heiko; SCHREURS, Sonja \& SCHROEYERS, Wouter (2017) Variation of natural radionuclides in non-ferrous fayalite slags during a one-month production period. In: Journal of environmental radioactivity, 172, p. 63-73.

DOI: 10.1016/j.jenvrad.2017.03.004

Handle: http://hdl.handle.net/1942/23398 


\section{Variation of natural radionuclides in non-ferrous fayalite \\ 2 slags during a one-month production period}

3. Tom Croymansa,

4. Indy Vandael Schreursa,

5. Mikael Hultb,

6. Gerd Marissens ${ }^{b}$,

7. Guillaume Lutter,

8. Heiko Strohb,

9. Sonja Schreursa,

10. Wouter Schroeversa,

- Natural radionuclides monitored in non-ferrous slag during 1 month production.

- Large activity concentration fluctuations of natural occurring radionuclides.

- Disequilibrium in the ${ }^{238} \mathrm{U}$ decay series and equilibrium in the ${ }^{232}$ Th decay series.

- Extensive comparison between different types of metallurgical slags.

- Continuous monitoring of the produced slag is advised to assure safe application.

\section{Abstract}

The European Basic Safety Standards (EU-BSS) describes a set of NORM (Naturally Occurring Radioactive Materials)-processing industries which produce residues known to be possibly enriched in NORs (Naturally Occurring Radionuclides). These residues can be used as a component in building materials aimed for public usage. The industrial processes, in which the residues are produced, are often complex and total monitoring can be challenging especially when the origin of the used raw materials varies. In this study the NORs present in non-ferrous fayalite slags of a secondary smelter facility, a NORM-processing industry according to the EU-BSS, were monitored daily during a one-month production period. In addition flue dust samples and feedstock samples, known to contain elevated levels of NORs, of the same period were measured. The survey involved the gamma-ray spectrometric analysis of the decay products from the ${ }^{238} \mathrm{U}$ and ${ }^{232} \mathrm{Th}$ decay chains, 
${ }^{235} \mathrm{U}$ and ${ }^{40} \mathrm{~K}$ using HPGe detectors. Secular equilibrium was observed for the slags, flue dust and feedstock samples in the ${ }^{232} \mathrm{Th}$ decay chain, in contrast to the ${ }^{238 \mathrm{U}}$ decay chain. During the month in question the ratios of maximum over minimum activity concentration were $3.1 \pm 0.5$ for ${ }^{40} \mathrm{~K}, 4 \pm 1$ for ${ }^{238} \mathrm{U}, 6 \pm 1$ for ${ }^{226} \mathrm{Ra}, 13 \pm 7$ for ${ }^{210} \mathrm{~Pb}, 4.5 \pm 0.6$ for ${ }^{228} \mathrm{Ra}$ and $4.7 \pm 0.7$ for ${ }^{228} \mathrm{Th}$ for the slags. Even with the activity concentration of the feedstock material ranging up to $2.1 \pm 0.3 \mathrm{kBq} / \mathrm{kg}$ for ${ }^{238 \mathrm{U}}, 1.6 \pm 0.2 \mathrm{kBq}$ for ${ }^{226} \mathrm{Ra}, 22 \pm 7 \mathrm{kBq} / \mathrm{kg}$ for ${ }^{210} \mathrm{~Pb}, 2.1 \pm 0.2 \mathrm{kBq} / \mathrm{kg}$ for ${ }^{228} \mathrm{Ra}$ and $2.0 \pm 0.4 \mathrm{kBq} / \mathrm{kg}$ for ${ }^{228} \mathrm{Th}$, none of the slag samples exceeded the exemption/clearance levels of the EU-BSS and RP-122 part II, which can respectively provide guidance under equilibrium and in absence of equilibrium. As each NORM-processing industry has its own complexity and variability, the observed variations point out that one should approach one-time measurements or low frequency monitoring methods cautiously. Low frequency measurements should be optimised depending on the discharge of the batches. A follow up of the industrial process and its output can provide important insights to assure a limited public exposure upon application of these industrial residues.

Finally a comparison is made with reported data on other metallurgical slags and the use of the slags in building materials is evaluated using the Activity Concentration Index (ACI) proposed by the EU-BSS.

\section{Introduction}

Each year over 400 million tons of metallurgical slags, a by-product from metal producing industries, are produced world-wide (van Oss, 2013). Due to the presence of Naturally Occurring Radionuclides (NORs) in the raw materials used by the metallurgical industries the produced metallurgical slag can contain enhanced concentrations of NORs. In Table 1 an overview is given on the activity concentrations of ${ }^{226} \mathrm{Ra},{ }^{232} \mathrm{Th}$ and ${ }^{40} \mathrm{~K}$ for different types of metallurgical slags reported in the literature. These activity concentrations are found in the intervals 2-69 kBq/kg, 2-130 kBq/ kg and 2-23 kBq/ kg for ${ }^{226} \mathrm{Ra},{ }^{232} \mathrm{Th}$ and ${ }^{40} \mathrm{~K}$, respectively. It must be noted that this list is not exhaustive and some data originate from samples of the 1980's. In several cases the number of measured samples is not specified and not all considered NORs $\left({ }^{226} \mathrm{Ra},{ }^{232} \mathrm{Th}\right.$ and $\left.{ }^{40} \mathrm{~K}\right)$ are reported. The data 
and nomenclature are shown as mentioned in the corresponding reference. Data on other radionuclides mentioned in the corresponding reference is not shown in Table 1. The two main classes of metallurgical slags are non-ferrous and ferrous slags (Piatak et al., 2015a). Especially for non-ferrous slags such as $\mathrm{Sn}, \mathrm{Nb}$ and $\mathrm{Cu}$ slags, higher activity concentrations can be found reaching up to (Table 1):

- $69 \mathrm{kBq} / \mathrm{kg}{ }^{226} \mathrm{Ra}, 130 \mathrm{kBq} / \mathrm{kg}{ }^{232} \mathrm{Th}$ and $23 \mathrm{kBq} / \mathrm{kg}{ }^{40} \mathrm{~K}$ for Sn slag,

- $\quad 5 \mathrm{kBq} / \mathrm{kg}{ }^{226} \mathrm{Ra}$ and $118 \mathrm{kBq} / \mathrm{kg}{ }^{232} \mathrm{Th}$ for $\mathrm{Nb}$ slag

- $\quad 2.1 \mathrm{kBq} / \mathrm{kg}{ }^{226} \mathrm{Ra}, 0.1 \mathrm{kBq} / \mathrm{kg}{ }^{232} \mathrm{Th}$ and $1.3 \mathrm{kBq} / \mathrm{kg}{ }^{40} \mathrm{~K}$ for Cu slag.

Non-ferrous slags typically consist mainly out of Fe and Si whereas the ferrous slags are typically rich in Ca and Si (Piatak et al., 2015a). The production of nonferrous slag is limited to approximately $12 \%$ of the total worldwide slag production (National Slag Association, 2013). Non-ferrous industries that process niobium ores or work on tin, lead or copper smelting and therefore produce $\mathrm{Nb}$, $\mathrm{Sn}, \mathrm{Pb}$ and $\mathrm{Cu}$ slags are specifically considered in Council directive 2013/59/Euratom, known as the European Basic Safety Standards (EU-BSS), as practices involving naturally-occurring radioactive materials (NORM). In addition residues of steel production are regulated by the EU-BSS for use in building materials. In Table 1, it is also demonstrated that a large range of activity concentrations can be found for a given type of metallurgical slag. For example for Sn slag, the activity concentrations range from 0.5 - $69 \mathrm{kBq} / \mathrm{kg}$ for ${ }^{226} \mathrm{Ra}, 0.2$ - 130 $\mathrm{kBq} / \mathrm{kg}$ for ${ }^{232} \mathrm{Th}$ and $0.3-23 \mathrm{kBq} / \mathrm{kg}$ for ${ }^{40} \mathrm{~K}$. The measured activity concentrations for different non-ferrous slags are in several cases higher than the activity concentrations for exemption or clearance of NORs in solid materials in secular equilibrium with their progeny, proposed by the EU-BSS (European Commission, 2014). The EU-BSS exemption/clearance levels were chosen in accordance with the exemption/clearance levels of the IAEA "Application of the concepts of exclusion, exemption and clearance". A global level benefits the industries processing and transporting these materials from an administrative and legislative point of view. These EU-BSS | IAEA levels are $1 \mathrm{kBq} / \mathrm{kg}$ for natural radionuclides from the ${ }^{238} \mathrm{U}$ and ${ }^{232} \mathrm{Th}$ decay series and $10 \mathrm{kBq} / \mathrm{kg}$ for ${ }^{40} \mathrm{~K}$ (Table 2) however these levels are only applicable if secular equilibrium in the decay series is obtained. The EU-BSS allows higher values in case of disequilibrium but 
does not specify which levels are recommended. RP (Radiation Protection)-122 specifies these values and applies of a summation rule for the radiological evaluation (Table 2) (European Commission, 2002).

Before use of non-ferrous slag can be allowed, the EU-BSS requires that the value of the activity concentration relative to the exemption/clearance levels is determined. In addition the EU-BSS specifies a screening index called the Activity Concentration Index (ACI) applicable for building materials containing these residues (Equation 1).

$$
A C I=\frac{A c_{R a 226}}{300 B q / k g}+\frac{A c_{T h 232}}{200 B q / k g}+\frac{A c_{K 40}}{3000 B q / k g}
$$

With Ac as activity concentration of the mentioned radionuclide expressed in $\mathrm{Bq} / \mathrm{kg}$.

According to the EU-BSS this index allows estimating the requirement that upon application of these building materials the public exposure is below the effective dose limit of $1 \mathrm{mSv}$ a year. An ACI value below 1 assumes that the dose limit of 1 $\mathrm{mSv}$ a year is not exceeded. The application of metallurgical slags in building materials is gaining interest and the applications depend on the chemical composition, cooling path, availability, price, etc. (Piatak et al., 2015a). Usage of metallurgical slags in tiles, in railway ballast, in roofing materials, in coloured glass and in cementitious materials are reported (Piatak et al., 2015b). The main usage is as a raw material in asphalt and concrete mixtures for road construction mainly for ferrous slag (Piatak et al., 2015b). Recently the application of nonferrous slag as a binder to produce inorganic polymers building materials was reported (Pontikes et al., 2013). Inorganic polymers (IPs) are novel types of building materials with lower $\mathrm{CO}_{2}$ emissions in comparison to concrete (Provis, 2014). IPs can be used in similar applications as conventional concrete (Provis and Van Deventer, 2014). In addition, other reuse and recycle options are reported, like usage as sand blasting material, as reprocessing material for secondary metal recovery and for environmental remediation (Al-jabri et al., 2011; Piatak et al., 2015b). Despite these applications, still large fractions of slags currently ends up on landfills (Piatak et al., 2015a). 
139 A common feature of the listed studies on metallurgical slags in Table 1, is that

140 the measurements represent a one-time sampling and that none of the considered 141 studies follow the output of the process over a period of time. Therefore no 142 information is available to verify to which extent variations in the industrial 143 process or in the origin of the incoming raw materials over time can impact the 144 activity concentration of the produced non-ferrous slag. The current study, which 145 focuses on non-ferrous fayalite slags produced in a secondary smelter for 146 production of different types of non-ferrous metals, aims to address this aspect. 147 The production during a one-month production period was monitored. Within 148 this framework the activity concentrations of NORs are evaluated against the 149 exemption/clearance levels of annex VII of the EU-BSS. The variation in activity 150 concentration of the long-living natural radionuclides is discussed, as well as the 151 (dis)equilibria which are present. Finally the ACI is discussed since these slags are 152 used for the production of IP building materials.

\section{Methods and materials}

\subsection{Samples}

158 The samples in this study originate from a secondary smelting plant aimed at the 159 production of different types of non-ferrous metals. The factory handles a broad 160 range of primary and secondary raw materials from industries listed in annex VI 161 of the EU-BSS as industries with naturally occurring radioactive materials 162 (European Council, 2014). The smelter facility is sorted under the category 163 tin/lead/copper smelting in annex VI of the new EU-BSS. Non-ferrous fayalite 164 slags are produced as by-product.

\subsubsection{Non-ferrous fayalite slag samples}

168 Every day, several smelting cycles are performed and with each cycle a different 169 amount of slag is produced. These residues are the remaining after the recovery 170 of non-ferrous metals from the feedstock by pyrometallurgical processes. 
171 Representative samples of slags from each smelting cycle were taken during a 172 one-month period. The samples were collected directly from the liquid bath 173 situated in the furnace. This implies that the sample is representative of the batch 174 and that it is homogeneous. The produced fayalite slags were cooled by water 175 quenching. In order to limit the number of samples for analysis and because the 176 slags are discharged daily, one sample for each day was produced based on 177 samples from several smelting cycles of that particular day. The relative 178 contribution of each smelting cycle sample to the daily sample was proportional 179 to the slag production quantity of each smelting cycle (Equation 2).

181 Composition daily sample $=\sum_{i=1}^{n} \frac{\text { Quantity production batch } i}{\text { Quantity day production }} * 100 \%$

183 All cycle samples were dry and milled to powders by disk milling. In total 31 slag 184 mixtures were produced corresponding to 31 consecutive days of slag production. 185 Each slag mixture dry mass varied between $80 \mathrm{~g}$ and $140 \mathrm{~g}$. The samples of a first 186 batch of slag samples were measured after a period of approximately 470 days 187 after sample collection. Samples from a second batch (indicated as second batch), 188 in total two fayalite slags samples, were sampled at a later date, prepared in the 189 exact same way as the first batch and measured after a period of approximately 190180 days after sample collection.

191 The slag samples are rich in aluminium oxides (typically 6\% (by mass)), iron 192 oxides (typically 55\% (by mass)) and silicon oxides (typically 23\% (by mass)).

\subsubsection{Flue dust samples}

The flue dust is recovered by leading the off-gasses through fabric filter units.

197 These are cleaned at regular time intervals by which the dust is transferred to dust 198 silos for temporary storage. By the cleaning action and the subsequent fluidization 199 of the dust for transport purposes, the dust is already mixed in the silos. Trucks 200 are loaded directly from those silos. At several places of the truckload, grab 201 samples are collected and mixed to form a homogeneous sample for 202 measurements. Nine different batches of dust samples were monitored during the 203 one month production period, containing mainly Zn, and minor amounts of other 
non-ferrous metals. The dry mass of the collected samples ranged from $42 \mathrm{~g}$ to 76

205 g. The samples were measured after a period of approximately 470 days after 206 sample collection.

\section{$\underline{2.1 .3 \quad \text { Feedstock samples }}$}

210 All feedstock materials are monitored upon arrival via a detection portal. As a

211 result of this screening one type of feedstock material with elevated activities is

212 selected for further investigations in the framework of this study. The considered

213 feedstock material is mainly a metallic by-product of a primary non-ferrous metal 214 producer, containing iron (> 70\%), and minor amounts of other metals. The 215 radioactivity is primarily resulting from slag inclusions, which are difficult to 216 separate from the metal phase. The considered feedstock material is a minor 217 fraction of the total feedstock materials used in the production process. Samples 218 for measurement were produced by mixing delivered lots (size from 25 to 50 ton) 219 homogeneously by mobile cranes, and subsequently performing several "coning 220 \& quartering" actions until a homogeneous and representative sample of about $221500 \mathrm{~kg}$ is reached. This sample is further downsized by the same techniques using 222 manual actions until a sample of circa $50 \mathrm{~kg}$ remains. Grab samples of this final 223 sample were used for measurements. Five different batches of feedstock materials 224 were monitored during the one month production period. The dry mass of these 225 samples ranged between $260 \mathrm{~g}$ and $570 \mathrm{~g}$. The samples were measured after a 226 period of approximately 470 days after sample collection.

\subsection{Radiological analysis}

230 Measurements were performed on different HPGe-detectors of the Radionuclide 231 Metrology Laboratory of JRC-Geel in Belgium. All detectors are located in the 225 232 m deep underground laboratory Hades located on the premises of the Belgian 233 Nuclear Centre SCK•CEN in Mol, Belgium except for Ge T-5 which is located above 234 ground. The detector details are listed in Table 3. The low background count rates 235 of the underground detectors were in the order of 200 to 400 counts per day in 236 the energy interval 40 to $2700 \mathrm{keV}$. The background count rate of individual peaks 
was mostly below 1 count per day. This low background is particularly important when measuring NORs that are known to be present in all detector systems. All samples for gamma-ray spectrometric analysis were transferred to radon tight Teflon containers and stored for at least 21 days to reach secular equilibrium

241 between ${ }^{226} \mathrm{Ra}$ and daughters. The slag and flue dust samples were positioned 2 $242 \mathrm{~mm}$ above the endcap of each HPGe-detector except for detector Ge-8 where the 243 samples were placed directly on the endcap. The feedstock samples were 244 positioned $11 \mathrm{~mm}$ above the endcap of the HPGe-detector. The measurement 245 times ranged from 2 to 7 days and the dead time was always below $1 \%$.

Canberra's Genie 2000 software was used for data acquisition and spectrum analysis. The EGSnrc (electron gamma shower National Research Council Canada) (Kawrakow et al., 2009). Monte Carlo code was used to calculate the full energy peak (FEP) efficiencies and the coincidence summing corrections. The Monte

251 Carlo code input consists of the sample's measured dimensions, composition and density, and the detector set-up. Isotropic and uncorrelated emission of the gamma-rays was assumed in the simulations. A homogeneous distribution of radionuclides in the sample and of the sample material in the sample container were two other assumptions that were adopted in all the calculations.

The radionuclides occurring in natural decay series of $238 \mathrm{U}$ and ${ }^{232} \mathrm{Th}$, as well as ${ }^{235} \mathrm{U}$ and ${ }^{40} \mathrm{~K}$ were investigated by their emitted gamma rays. An overview of the used gamma lines is found in Croymans et al. 2016 (Croymans et al., 2016).

261 A weighted mean of the activity was calculated for radionuclides with multiple gamma-rays. The activity of the different gamma-rays was taken into account. The

263 Decay Data Evaluation Project (DDEP) website was used for the nuclear decay 264 data (Laboratoire national Henri Becquerel, 2016).

265 The $186 \mathrm{keV}$ peak is a doublet with contributions from ${ }^{235} \mathrm{U}(185.7 \mathrm{keV})$ and ${ }^{226} \mathrm{Ra}$ 266 (186.2 keV). By subtracting the contribution from ${ }^{226} \mathrm{Ra}$, which activity was 267 determined from its daughters ${ }^{214} \mathrm{~Pb}$ and ${ }^{214} \mathrm{Bi}$, from the $186 \mathrm{keV}$ doublet peak, the 268 activity of ${ }^{235} \mathrm{U}$ is calculated. In addition this result was confirmed by the other 269 three main gamma lines of $235 \mathrm{U}$ i.e. $143.8 \mathrm{keV}, 163.4 \mathrm{keV}$ and $205.3 \mathrm{keV}$. As natural 
isotopic abundance is expected for ${ }^{235} \mathrm{U}$ in these "non-nuclear" samples, one can see the measured ${ }^{238} \mathrm{U} /{ }^{235} \mathrm{U}$ activity ratio as a quality control of the measurement.

The activity concentration (in this paper meaning the activity per unit of mass) was determined by dividing the final activity determined for each radionuclide by the measured dry mass of the sample. All the activity concentrations are determined on the measurement date, mentioned in section 2.1 for each sample.

277 Thus, no decay correction to the sampling date was made. The time of 278 measurement between the first slag sample and the last slag sample was 42 days.

The uncertainties of the obtained activity concentrations are the combined standard uncertainties calculated according to the GUM (Guide to the expression of uncertainty in measurement) (JCGM WG1, 2008). When combining several gamma-rays to one activity-value for one radionuclide and when combining activity-values from several daughters to one mother radionuclide using weighted means, the correlated parameters were excluded from the calculation of the uncertainty of the weighted mean and added separately afterwards in quadrature in order not to obtain unrealistic and far too low final uncertainties.

The ACI was calculated for slag 1 to 31 using the activity concentration of ${ }^{226} \mathrm{Ra}$, ${ }^{232} \mathrm{Th}$ and ${ }^{40} \mathrm{~K}$ (Equation 1). The EU-BSS assumes equilibrium between ${ }^{232} \mathrm{Th}$ and ${ }^{228} \mathrm{Ac}$, and therefore the activity concentration of ${ }^{228} \mathrm{Ac}$ is used. The ACI calculation performed here assumes that the building material is constructed solely of the non-ferrous slag. Novel developments in IP production allow developing building materials solely out of non-ferrous fayalite slag (Kriskova et al., 2015).

Uncertainty of the ACI is calculated like in Equation 3

$$
u(I)=\sqrt{\left.\left(\frac{1}{300}\right)^{2} u^{2}\left(A c_{226 R a}\right)+\left(\frac{1}{200}\right)^{2} u^{2}\left(A c_{232 T h}\right)+\left(\frac{1}{3000}\right)^{2} u^{2}\left(A c_{40 K}\right)\right)}
$$
concentration of the mentioned radionuclide. 


\section{Results \& Discussion}

Figures 1 and 2 show the measured activity concentrations of radionuclides from the ${ }^{232} \mathrm{Th}$ and ${ }^{238} \mathrm{U}$ decay series in the slag mixtures. Table 4 shows the minimum and maximum activity concentrations, the ratio of the maximum over the minimum activity concentration and the ratio of different long living radionuclides over each other for feedstock material, flue dust and slag samples.

\subsection{Assessment of radiological equilibrium in samples}

\subsubsection{The ${ }^{232}$ Th decay series}

The activity concentrations of the relatively short-lived ${ }^{224} \mathrm{Ra},{ }^{212} \mathrm{~Pb},{ }^{212} \mathrm{Bi}$ and ${ }^{208} \mathrm{Tl}$

316 (corrected for its branching) were equal within the measurement uncertainties.

317 Their weighted mean value gave the activity concentration for ${ }^{228} \mathrm{Th}\left(\mathrm{t}_{1 / 2}=1.9126\right.$ years). The activity concentration of the short-lived ${ }^{228} \mathrm{Ac}$ was in equilibrium with its mother ${ }^{228} \mathrm{Ra}\left(\mathrm{t}_{1 / 2}=5.75\right.$ years). Looking at Table 4 the ratio of ${ }^{228} \mathrm{Ra}$ over ${ }^{228} \mathrm{Th}$ equals 1 in the feedstock material samples, flue dust samples and slag samples. For the slags, this equilibrium is not likely to have been established in the relatively short time ( $\sim 470$ days, two-thirds of the $t_{1 / 2}$ of ${ }^{228} \mathrm{Th}$, and $\sim 180$ days, a quarter of the $t_{1 / 2}$ of ${ }^{228} \mathrm{Th}$; respectively for Batch 1 and 2 ) between the production and the measurement. This means that $\mathrm{Ra}$ is not separated from Th during the industrial process of non-ferrous metal production. Th and Ra are both lithophilic and will therefore end up in the slag phase (Bourdon et al., 2003; White, 2013). The affinity for silicates of both radionuclides confirms the unaffected equilibrium during the industrial process. Often in literature, equilibrium is assumed between ${ }^{232} \mathrm{Th}$ and ${ }^{228} \mathrm{Ra}$, here the activity of ${ }^{228} \mathrm{Ra}$ is shown since this one is actually measured. 
335 For the ${ }^{238} \mathrm{U}$ series (Figure 2), the activity concentrations of ${ }^{234} \mathrm{Th}$ and ${ }^{234 \mathrm{mPa}}$ 336 represent the activity concentration of $238 \mathrm{U}$, secular equilibrium is assumed in case 337 of the slags since measurements of the slags took place 470 days after the 338 production. The activity concentrations of ${ }^{214} \mathrm{~Pb}$ and ${ }^{214} \mathrm{Bi}$ were equal within the 339 measurement uncertainties so their mean value was taken as the activity for ${ }^{226} \mathrm{Ra}$. 340 The ${ }^{226} \mathrm{Ra}$ activity concentrations are for the slags a factor $1.7 \pm 0.4$ to $7 \pm 2$ lower 341 than the activity concentration of ${ }^{238} \mathrm{U}$ (Table 4). This indicates an absence of 342 equilibrium between ${ }^{238} \mathrm{U}$ and ${ }^{226} \mathrm{Ra}$ in the slags. This absence is surprising since $343 \mathrm{U}$, Th and $\mathrm{Ra}$, all are part of the first section of the ${ }^{238} \mathrm{U}$ decay series ( ${ }^{238} \mathrm{U}$ to ${ }^{226} \mathrm{Ra}$ ) 344 and are lithophilic elements (Bourdon et al., 2003; White, 2013). So these elements have a high affinity for silicates and are expected to mainly end up in the slag phase.

This disequilibria is also present in the investigated feedstock material but less distinct, with a minimum and maximum ratio ${ }^{238} \mathrm{U} /{ }^{226} \mathrm{Ra}$ of $1.2 \pm 0.2$ and $1.9 \pm 0.3$ respectively (table 4). Looking at another output material of the industrial process, the flue dust demonstrates an even more outspoken absence of equilibria with a minimum and maximum ${ }^{238} \mathrm{U} /{ }^{226} \mathrm{Ra}$ ratio of respectively $10 \pm 3$ and $30 \pm$ 10. It must be noted that the ${ }^{238} \mathrm{U}$ (maximum $50 \pm 10 \mathrm{~Bq} / \mathrm{kg}$ ) and ${ }^{226} \mathrm{Ra}$ (maximum $3.3 \pm 0.2 \mathrm{~Bq} / \mathrm{kg}$ ) activity concentrations of the flue dust samples are low in comparison with ${ }^{238} \mathrm{U}$ (minimum $42 \pm 4 \mathrm{~Bq} / \mathrm{kg}$ ) and ${ }^{226} \mathrm{Ra}$ (minimum $14 \pm 2 \mathrm{~Bq} / \mathrm{kg}$ ) activity concentrations of the slag samples (Table 4). In addition, per ton slag approximately $25 \mathrm{~kg}$ of flue dust is produced. This means transport of $238 \mathrm{U}$ and ${ }^{226} \mathrm{Ra}$ to the flue gasses is limited. The activity concentrations of ${ }^{238} \mathrm{U}$ and ${ }^{226} \mathrm{Ra}$ in the metallic fractions are low - this is confirmed by the company, however no data can be made publicly available. Regarding the lithophile properties of $\mathrm{U}$ and $\mathrm{Ra}$ and their limited absolute transport, it is believed that other sources of NORs which have a higher degree of disequilibrium than the measured feedstock material are present and consequently explain the relatively high level of disequilibria in the slag samples. The activity concentrations ratios of ${ }^{210} \mathrm{~Pb}$ over ${ }^{226} \mathrm{Ra}$ in the non-ferrous slags range between $0.14 \pm 0.09$ and $1.4 \pm 0.5$ (Table 4). In nine cases an absence of 
equilibrium is observed and the activity concentration of ${ }^{210} \mathrm{~Pb}$ is lower than the activity concentration of ${ }^{226} \mathrm{Ra}$. However in slags 6 to 11, slags 17 to 23, slag 25 and slags 27 to 29 equal activity concentrations are measured (Figure 2). It is

371 important to note that the observed equal activity concentrations of ${ }^{226} \mathrm{Ra}$ and $372{ }^{210} \mathrm{~Pb}$ cannot originate from the instalment of equilibrium of ${ }^{210} \mathrm{~Pb}$ with ${ }^{226} \mathrm{Ra}$ 373 during or after processing, since the half-life of $210 \mathrm{~Pb}$ is 22.23 years. Table 4 shows 374 that for the flue dust the minimum and maximum ratios ${ }^{210} \mathrm{~Pb} /{ }^{226} \mathrm{Ra}$ are $110 \pm 30$ 375 and $900 \pm 300$ respectively and for the feedstock material they are $8 \pm 3$ and $20 \pm$ 3767 respectively. So the absence of equilibrium is already present in the feedstock 377 material but is less pronounced for the slag samples and more pronounced for the 378 flue dust samples. An enrichment in $\mathrm{Pb}$ concentration and enhanced ratios $379{ }^{210} \mathrm{~Pb} /{ }^{226} \mathrm{Ra}$ in dust samples were also observed by Khater and Bakr which studied 380 the transport of $210 \mathrm{~Pb}$ transport in metallurgical industries (Khater and Bakr, 381 2011). The transport of $\mathrm{Pb}$ towards flue dust and fumes can be subscribed to the 382 volatile nature of $\mathrm{Pb}$. In addition the ratio ${ }^{210} \mathrm{~Pb}$ over ${ }^{226} \mathrm{Ra}$ in the slags samples is 383 influenced by the transport of $\mathrm{Pb}$ towards the metallic phase i.e. the produced 384 metal alloy. This transport is depending on the reduction potential in the furnace 385 of the investigated smelter facility. Strong reducing conditions favor the transport 386 of $\mathrm{Pb}$ towards the metal phase. No ${ }^{210} \mathrm{~Pb}$ was measured in slags 1 to 5 and the Minimum Detectable Activity (MDA) with a confidence limit of $95 \%$ was below $20 \mathrm{~Bq} / \mathrm{kg}$ for slags 1 to 4 and $160 \mathrm{~Bq} / \mathrm{kg}$ 390 for slag 5. The MDA of slag 5 is higher due to the thicker dead layer of detector Ge3913 , which impacts the FEP for the low-energy gamma-ray of $210 \mathrm{~Pb}$.

393 The ratio of activity concentrations ${ }^{238} \mathrm{U} /{ }^{235} \mathrm{U}$ of all slags agreed within the 394 uncertainties (except for slag 19) with the expected value of 21.6. The measured $395238 \mathrm{U} /{ }^{235} \mathrm{U}$ ratios (Figure 3) indicate therefore the expected natural isotopic 396 composition. This is an important quality control measure, which indicates that 397 the gamma-spectrometric measurements were robust. 
401 Potassium-40 is not a part of a decay series and has lithophilic properties (White,

402 2013). The ${ }^{40} \mathrm{~K}$ activity concentrations in the slags vary between $26 \pm 8 \mathrm{~Bq} / \mathrm{kg}$ and

$40380 \pm 10 \mathrm{~Bq} / \mathrm{kg}$ (Figure 4 and Table 4).

404

\subsection{Temporal variation in the activity concentrations}

407 The ratios of the maximum measured activity concentration over the minimum 408 activity concentration for each long living radionuclide in the different materials 409 (Table 4) indicate significant fluctuations. For the slags, the lowest ratio was $3.1 \pm$ 4100.5 for ${ }^{40} \mathrm{~K}$ and the highest ratio was $13 \pm 7$ for ${ }^{210} \mathrm{~Pb}$ whereas for the flue dust 411 samples the lowest ratio was $2.0 \pm 0.3$ for ${ }^{228} \mathrm{Ra}$ and the highest ratios was $4.3 \pm$ 4120.7 for ${ }^{40} \mathrm{~K}$. The variations in the non-ferrous slag and flue dust samples can be 413 explained as the smelter facility uses a mixture of primary and secondary raw 414 materials. The radiological content of the input materials is strongly depending on 415 the origin and as the data of the investigated feedstock material (Table 4 and 416 Figure 4) suggests also variations occur even when the origin of the input material 417 is the same (IAEA, 2003). For the feedstock materials the lowest observed 418 maximal/minimal ratio was $2.2 \pm 0.6$ for ${ }^{228} \mathrm{Th}$ and the highest observed ratio was $4199 \pm 7$ for ${ }^{40} \mathrm{~K}$.

421 The selection of the input material is driven by economical factors and optimised 422 in function of the produced metals in order to obtain a stable elemental 423 composition in the slags and metals (Nakamura and Halada, 2015). In addition the 424 company states that the amount of metals present in the input stream influences 425 the quantity of slags and metals produced. Both quantities are also influenced by 426 the process parameters. Therefore differences occur between the production 427 batches and as a result a large variation in activity concentration is observed even 428 in the studied one-month period. It is clear that conclusions based on the 429 radiological characterisation of one day production can be very misleading.

430 These measures will only bear information on a specific time and not on the 431 variation of the activity concentrations. Drawing conclusions based on a one-time 432 sampling or low frequency sampling in order to ensure radiation protection of 433 general public and workers should be performed cautiously. The authors 
recommend performing radiological measurements depending on the frequency

435 of the discharge of the residues taking into account the complexity and variability

436 of the facility/industry.

3.3 Comparison of activity concentrations with the literature.

As discussed in the introduction and shown in Table 1 metallurgical slags can contain various amounts of NORs. Overall the activity concentrations of the measured fayalite slags of this study are low compared with the metallurgical slags of Table 1 . The quantity of slag per produced quantity of metal can vary depending on the production process. Gorai et al. estimated that for every ton of copper 2.2 ton of slag is produced whereas Proctor et al. estimated that 220-370

$446 \mathrm{~kg}$ blast furnace slag is produced per ton of produced iron (Gorai and Jana, 2003; 447 Proctor et al., 2000). This in combination with the chemical characteristics of the 448 slags and metals produced influences the transport of radionuclides and gives rise 449 to enrichments or depletions in comparison with the input materials. Here the 450 slags originate from a secondary smelter facility, with a tonnage ratio of produced 451 slags over metal above 1 and with scrap being the main input material for the 452 recycling of metals. Since not all the feedstock contains enhanced concentrations 453 of NORs, the result is that the activity concentration of the resulting slag is lower 454 than the most active components in the feedstock.

\subsection{Evaluation in function of legislative criteria}

\subsubsection{Evaluation considering the exemption and clearance levels}

460 Except for ${ }^{210} \mathrm{~Pb}$ in the flue dust samples, all activity concentrations of the long 461 living radionuclides in the slag and flue dust samples are below the EU-BSS | IAEA 462 and RP-122 exemption/clearance levels (Table 2 and 4). This is in contrast with 463 the feedstock materials for which all radionuclides - except for ${ }^{235} \mathrm{U}$ and ${ }^{40} \mathrm{~K}$ - are 464 above the exemption/clearance levels. 
RP-122 part II specifies the exemption/clearance levels even when the secular equilibrium is absent via a summation rule. For slag 18 - having the highest observed activity concentrations - the result of this summation rule is $0.52 \pm 0.03$, well below the exemption/clearance level of 1 .

\subsubsection{Evaluation for use as building material considering the ACI}

Figure 5 shows the variation of the ACI when the fayalite slag is solely used $(100 \%)$ to construct a building material. No day production batch exceeded the index value of 1 , therefore every day production batch can be used as an building material. It must be noted that the highest observed activity concentrations (slag 18) are approximately a factor 12,10 and 120 below the exemption/clearance levels of the EU-BSS for respectively ${ }^{226} \mathrm{Ra}$, ${ }^{232} \mathrm{Th}$ and ${ }^{40} \mathrm{~K}$, however the index has a value of approximately 0.8 . So being well below the exemption/clearance levels does not necessarily imply that is in accordance with the limits applying to building materials.

Finally, it was observed that when only minor amounts of feedstock material, containing activity concentrations well above the EU-BSS exemption/clearance levels are used, the activity concentrations of the slags are below the exemption/clearance levels and the ACI value of 1 is not exceeded.

Portal monitoring provides valuable information on the input materials that could be of concern. Nevertheless setting up holistic balances containing information on the activity concentration of all input materials per produced batch of output material can be difficult and cumbersome due to the complexity of industrial processes and large number of different input materials used. Therefore one cannot exactly determine the impact of "elevated" feedstock materials so output monitoring in function of discharges provides the necessary information whether the residues are exempted or if they can be used in building materials considering the EU-BSS.

\section{Conclusion}


499 The current study monitored different materials processed in a non-ferrous 500 smelter facility, which fits within the framework of the EU-BSS. Equilibria are 501 discussed for the ${ }^{232} \mathrm{Th}$ and ${ }^{238} \mathrm{U}$ decay series. The ${ }^{232} \mathrm{Th}$ decay series was found to 502 be in equilibrium for all the slags, measured feedstock material and flue dust. This 503 was not the case for ${ }^{238} \mathrm{U}$ decay series due to lack of equilibrium in the feedstock 504 material and the impact of the industrial process. The activity concentrations of 505 the slags were all below the provided exemption/clearance levels of the EU-BSS 506 and RP-122 part II, and are also low in comparison to slags reported in literature. 507 The activity concentrations of the flue dust samples were all except for ${ }^{210} \mathrm{~Pb}$ 508 below the exemption/clearance levels. For the feedstock material only ${ }^{40} \mathrm{~K}$ and ${ }^{235} \mathrm{U}$ were below the exemption/clearance levels. In addition the ACI is not a restriction regarding the use of these non-ferrous slags to produce building 511 materials.

512 Comparing the minimum and maximum observed activity concentrations for 513 different radionuclides, differences up to a factor 13, 4.3 and 9 are registered for 514 respectively slag, flue dust and feedstock samples. These variations occur due to 515 heterogeneity within the same input materials, and variation in input materials, 516 input and output quantity and in the process parameters. The variations in activity 517 concentrations indicate that using one-time sampling or applying a low frequency 518 of sampling is inappropriately for the considered industrial case. One-time 519 sampling leads to a misleading conclusion regarding the radiological output of the 520 production process in particular in complex systems. Consequently drawing 521 conclusions to ensure radiation protection should be performed cautiously and 522 the complexity and variability of the facility or industry should be taken into 523 account. Over the long time, production processes tend to change in time due to 524 innovations, regulations and economic factors. These factors will impact both 525 input and output and subsequently can also influence the radiological content of 526 the residues. The frequency of the radiological monitoring should be optimized 527 for a given plant in order to ensure radiation protection, especially when the 528 residues are aimed towards reuse in public applications. The authors recommend 529 monitoring depending on the frequency of the discharge of these residues. 


\section{Acknowledgements}

533 The authors would like to thank the company for providing the samples and

534 collaboration during this study. This work was supported by the European

535 Commission within HORIZON2020 via the EURATOM project EUFRAT for

536 transnational access. The authors would also like to acknowledge networking

537 support by the COST Action TU1301. www.norm4building.org.

\section{Reference list}

540
Al-jabri, K.S., Al-saidy, A.H., Taha, R., 2011. Effect of copper slag as a fine aggregate on the properties of cement mortars and concrete. Constr. Build. Mater. 25, 933-938.

ALamoudi, Z.M., ALmehmadi, F.G., 2013. Concentrations of the Naturally Occurring Radioactive Materials in waste samples from iron production the carbon filters used in Saudi Arabia. Life Sci. J. 10, 641-647.

Baltas, H., Kiris, E., Ustabas, İ., Yilmaz, E., Sirin, M., Kuloglu, E., Erdogan Gunes, B., 2014. Determination of natural radioactivity levels of some concretes and mineral admixtures in Turkey. Asian J. Chem. 26, 3946-3952. doi:10.1093/jae/ejm029

Bourdon, B., Turner, S., Henderson, G.M., Lundstrom, C.C., 2003. Introduction to U-series Geochemistry. Rev. Mineral. Geochemistry 52, 1-21.

Brodén, K., Ab, S.R., Sandell, Y., 2001. Radioactivity in commercially available metals.

Cabanekova, H., 1996. The concentration of natural radionuclides in various types of building materials in slovakia. J. Radioanal. Nucl. Chem. 209, 142144.

Cabáneková, H., 2008. Building materials as the source of radiation load of Slovak population.

Chinchón-payá, S., Piedecausa, B., Hurtado, S., Sanjuán, M.A., Chinchón, S., 2011. Radiological impact of cement, concrete and admixtures in Spain. Radiat. Meas. 46, 734-735.

Crockett, G.M., Smith, K.R., Oatway, W.B., Mobbs, S.F., 2003. NRPB-W48 Radiological impact on the UK population of industries which use or produce materials containing enhanced levels of naturally occurring radionuclides Part II: The steel production industry.

Croymans, T., Schroeyers, W., Krivenko, P., Kovalchuk, O., Pasko, A., Hult, M., Marissens, G., Lutter, G., Schreurs, S., 2016. Radiological characterization and evaluation of high volume bauxite residue alkali activated concretes. J. Environ. Radioact.

Ene, A., Pantelica, A., 2011. Characterization of Metallurgical slags using low-level gamma-ray spectrometry and neutron activation analysis. Rom. J. Phys. 56, 1011-1018.

European Commission, 2002. Radiation protection 122 practical use of the 
concepts of clearance and exemption Part II application of the concetps of exemption and clearance to natural radiation sources.

European Council, 2014. Laying down basic safety standards for protection against the dangers arising from exposure to ionising radiation, and repealing directives 89/618/Euratom, 90/641/Euratom, 96/29/Euratom, 97/43/Euratom and 2003/122/Euratom. Off. J. Eur. Union 1-73.

Gallyas, M., Torok, I., 1984. Natural radioactivity of raw materials and products in the cement industry. Radiat. Prot. Dosimetry 7, 69-71.

Garcia, M.A.A., 2009. Caracterização Radioquímica E Impacto Radiológico Ambiental No Processamento De Cassiterita Para Produção.

Gilmore, J.C., Jackson, R.G., 1992. Radiological hazards from deposits of Tinsmelting slag and the problems of site clearance and disposal, in: Proceedings of the Eighth International Congress on Radiation Protection (IRPA8) of the International Radiation Protection Association, Montreal. pp. 1408-1411.

Gorai, B., Jana, R.K., 2003. Characteristics and utilisation of copper slag - a review. Resour. Conserv. Recycl. 39, 299-313.

Hughes, J.S., Harvey, M.P., 2008. A Study on the Transport of Naturally-Occurring Radioactive Material.

IAEA, 2004. Application of the Concepts of Exclusion, Exemption and Clearance Safety Guide RS-G-1.7.

IAEA, 2003. Extent of Environmental Contamination by Naturally Occurring Radioactive Material (NORM) and Technological Options for Mitigation Technical reports series no. 419.

Ismail, B., Teng, I.L., Samudi, Y.M., 2011. Relative radiological risks derived from different TENORM wastes in Malaysia. Radiat. Prot. Dosimetry 147, 600607.

JCGM WG1, 2008. Evaluation of measurement data - Guide to the expression of uncertainty in measurement.

Jeong, J., Baik, M., Park, C., Park, T., Ko, N., Yoon, K.H., 2014. A basic study on the radiological characteristics and disposal methods of NORM Wastes. J. Nucl. Fuel Cycle Waste Technol. 12, 217-233.

Kawrakow, I., Mainegra-Hing, E., Tessier, F., Walters, B.R.B., 2009. The EGSnrc C++ class library. NRC Rep. PIRS-898 (rev A).

Khater, A.E.M., Bakr, W.F., 2011. Technologically enhanced $210 \mathrm{~Pb}$ and $210 \mathrm{Po}$ in iron and steel industry. J. Environ. Radioact. 102, 527-530. doi:10.1016/j.jenvrad.2011.02.002

Kontol, K.M., Ahmad, S.H.S.S., Omar, M., 2007. Radiological impact assessment for landfill disposal of NORM wastes in Malaysia, in: Naturally Occurring Radioactive Material ( NORM V). pp. 355-359.

Kriskova, L., Jones, P.T., Jannsen, H., Blanpain, B., Pontikes, Y., 2015. Synthesis and Characterisation of Porous Inorganic Polymers from Fayalite Slag. Slag Valoris. Symp. Zero Waste 4, 227-230.

Laboratoire national Henri Becquerel, 2016. Decay Data Evaluation Project http://www.nucleide.org/DDEP.htm (accessed 5.22.16).

Lehmann, R., 1996. Strahlenbelastung durch natürliche radionuklide in baumaterialien, fossilen brennstoffen und Dungemitteln. Bundesamt für Strahlenshutz, Berlin 135-156.

Leopold, K., Weiss, D., 2003. New approach to assessment and reduction of 
health risk and environmental impact originating from TENORM according to requirements of EU directive 96/29.

Muntean, L.E., Cosma, C., Moldovan, D. V., 2014. Measurement of natural radioactivity and radiation hazards for some natural and artificial building materials available in Romania. J. Radioanal. Nucl. Chem. 299, 523-532.

Mustonen, R., 1984. Natural radioactivity in and radon exhalation from Finnish building materials. Heal. Phys. Soc. 46, 1195-1203.

Nakamura, T., Halada, K., 2015. Urban Mining Systems.

National Slag Association, 2013. Common uses for slag http://www.nationalslag.org/common-uses-slag (accessed 5.22.16).

NORM4Building, 2016. Database of NORM4Building http://norm4building.org/db/ (accessed 7.1.16).

Omar, M., 2000. NORM waste management in Malaysia, in: International Conference on the Safety of Radioactive Waste Management. pp. 89-92.

Omar, M., Hamzah, M.S., Wood, A.K., 2008. Radioactive disequilibrium and total activity concentration of NORM waste. J. Nucl. Relat. Technol. 5, 47-56.

Pensko, J., Stpiczynska, Z., Blaton-Albicka, K., 1980. Emanating Power of Radon222 Measured in Building Materials Original from Typical Building Materials Used in Poland Original from, in: CONF-780422 (VOL. 2). pp. 1407-1414.

Pepin, S., 2013. Technische leidraad voor de operatoren van installaties voor de verwerking, de opwaardering en de recyclage van de NORM reststoffen.

Piatak, Parsons, M.B., Seal, R.R., 2015a. Applied Geochemistry Characteristics and environmental aspects of slag : A review, Applied Geochemistry.

Piatak, Parsons, M.B., Seal, R.R., 2015b. Characteristics and environmental aspects of slag: A review. Appl. Geochemistry.

Pires do Rio, M.A., Amaral, E.C.S., Fernandes, H.M., Rochedo, E.R.R., 2002. Environmental radiological impact associated with non-uranium mining industries: A proposal for screening criteria. J. Environ. Radioact. 59, 1-17.

Pontikes, Y., Machiels, L., Onisei, S., Pandelaers, L., Geysen, D., Jones, P.T., Blanpain, B., 2013. Slags with a high $\mathrm{Al}$ and Fe content as precursors for inorganic polymers. Appl. Clay Sci. 73, 93-102.

Proctor, D.M., Fehling, K.A., Shay, E.C., Wittenborn, J.L., Green, J.J., Avent, C., Bigham, R.D., Connolly, M., Lee, B., Shepker, T.O., Zak, M.A., 2000. Physical and chemical characteristics of blast furnace, basic oxygen furnace, and electric arc furnace steel industry slags. Environ. Sci. Technol. 34, 15761582.

Provis, J.L., 2014. Geopolymers and other alkali activated materials: why, how, and what? Mater. Struct. 47, 11-25. doi:10.1617/s11527-013-0211-5

Provis, J.L., Van Deventer, J.S.J., 2014. Alkali Activated Materials.

Puertas, F., Alonso, M.M., Torres-Carrasco, M., Rivilla, P., Gasco, C., Yagüe, L., Suárez, J.A., Navarro, N., 2015. Radiological characterization of anhydrous/hydrated cements and geopolymers. Constr. Build. Mater. 101, 1105-1112.

Ryan, T.P., Janssens, A., Henrich, E., Daroussin, J.-L., Hillis, Z.K., Meijne, E.I.M., 2004. Industries giving rise to NORM discharges in the European Union - A review, in: Naturally Occuring Radioactive Materials (NORM IV). pp. 169185.

Sahagia, M., Luca, A., Antohe, A., Ioan, R., Tanase, M., Garcia Torano, E., 2014. Comparison of analysis methods for the characterisation of the radioactive 

content of metallurgical slag used within the EURAMET-EMRP JRP IND04 metrometal. Rom. Reports Phys. 66, 649-657.

Sharaf, M., Mansy, M., El Sayed, A., Abbas, E., 1999. Natural radioactivity and radon exhalaton rates in building materials used in Egypt. Radiat. Meas. 31, 491-495.

Skowronek, J., Dulewski, J., 2005. NORM in Polish industry.

Smodis, B., Repinc, U., Benedik, L., 2006. Identification and inventory of TENORM sources in Slovenia. Czechoslov. J. Phys. 56, 37-42.

Sofilic, T., Bariši, D., Grahek, Ž., Cerjan-stefanovi, Š., Rastov, A., Mio, B., 2004. Radionuclides in metallurgical products and waste. Acta Metall. Slovaca 10, 29-35.

Sofilić, T., Barišić, D., Rastovčan Mioč, A., Sofilić, U., 2010a. Radionuclides in steel slag intended for road construction. J. Radioanal. Nucl. Chem. 284, 73-77.

Sofilic, T., Barisic, D., Sofilic, U., 2011. Natural radioactivity in steel slag aggregate. Arch. Metall. Mater. 56, 627-634. doi:10.2478/v10172-011-0068-y

Sofilić, T., Barišić, D., Sofilić, U., 2010b. Monitoring of 137Cs in electric arc furnace steel making process. J. Radioanal. Nucl. Chem. 284, 615-622.

Sofilic, T., Barišic, D., Sofilic, U., Đurokovic, M., 2011. Radioactivity of some building and raw materials used in Croatia. Polish J. Chem. Technol. 13, 2327.

Taha, R., Sirin, O., Sadek, H., 2014. Beneficial use of Qatar's steel slag and gravel deposits in road construction. Int. J. waste Resour. 4, 1-7.

Tanase, G., Tanase, M., 2003. Natural radioactivity in iron and steel materials by low-level gamma spectrometry. Rom. J. Phys. 48, 363-368.

Turhan, S., 2008. Assessment of the natural radioactivity and radiological hazards in Turkish cement and its raw materials. J. Environ. Radioact. 99, 404-414.

Ugur, F.A., Turhan, S., Sahan, H., Sahan, M., Goren, E., Gezer, F., Yegingil, Z., 2013. Investigation of the activity level and radiological impacts of naturally occurring radionuclides in blast furnace slag. Radiat. Prot. Dosimetry 153, 502-508.

Van Der Steen, J., 2004. Regulatory approaches for NORM residues in the Netherlands, in: Regulatory and Management Approaches for the Control of Environmental Residues Containing Naturally Occurring Radioactive Material (NORM). pp. 61-73.

van Oss, H.G., 2013. 2011 Minerals Yearbook: Slag-Iron and Steel, 2011 Minerals Yearbook.

Vanmarcke, H., Paridaens, J., Froment, P., Cauteren, J. Van, Timmermans, C., Cosemans, C., Sassi, F., 2010. Identification and characterization of NORM industries in Belgium, in: Proceedings of IRPA12: 12. Congress of the International Radiation Protection Association: Strengthening Radiation Protection Worldwide-Highlights, Global Perspective and Future Trends.

Wendling, L.A., Binet, M.T., Yuan, Z., Gissi, F., Koppel, D.J., Adams, M.S., 2013. Geochemical and ecotoxicological assessment of iron- and steel-making slags for potential use in environmental applications. Environ. Toxicol. Chem. 32, 2602-2610.

White, W.M., 2013. Chapter 7: Trace elements in Igneous processes, in: Geochemistry. pp. 259-313.

Xirouchakis, D., Manolakou, V., 2011. Properties of an EAf slag produced in 

Greece : a construction material for sustainable growth. 5th Int. Conf. Bitum. Mix. pavements. investigation of radioactivity of raws and building materials. Cent. Lab. Radiol. Prot. Bi-annual Rep. 1994-1995 51-55.

Zak, A., Biernacka, M., Jagielak, J., Lipinski, P., 1993. Investigations of radioactivity of building raws and materials. Nukleonika 38, 51-70.

Żak, A., Isajenko, K., Piotrowska, B., Kuczbajska, M., Ząbek, A., Sczygielski, T., 2008. Natural radioactivity of wastes. Nukleonika 55, 387-391. 
Figure 2: Activity concentration of 31 slag samples for the ${ }^{238} \mathrm{U}$ decay series (coverage factor, $\mathrm{k}=2$ ).

\section{Figures}

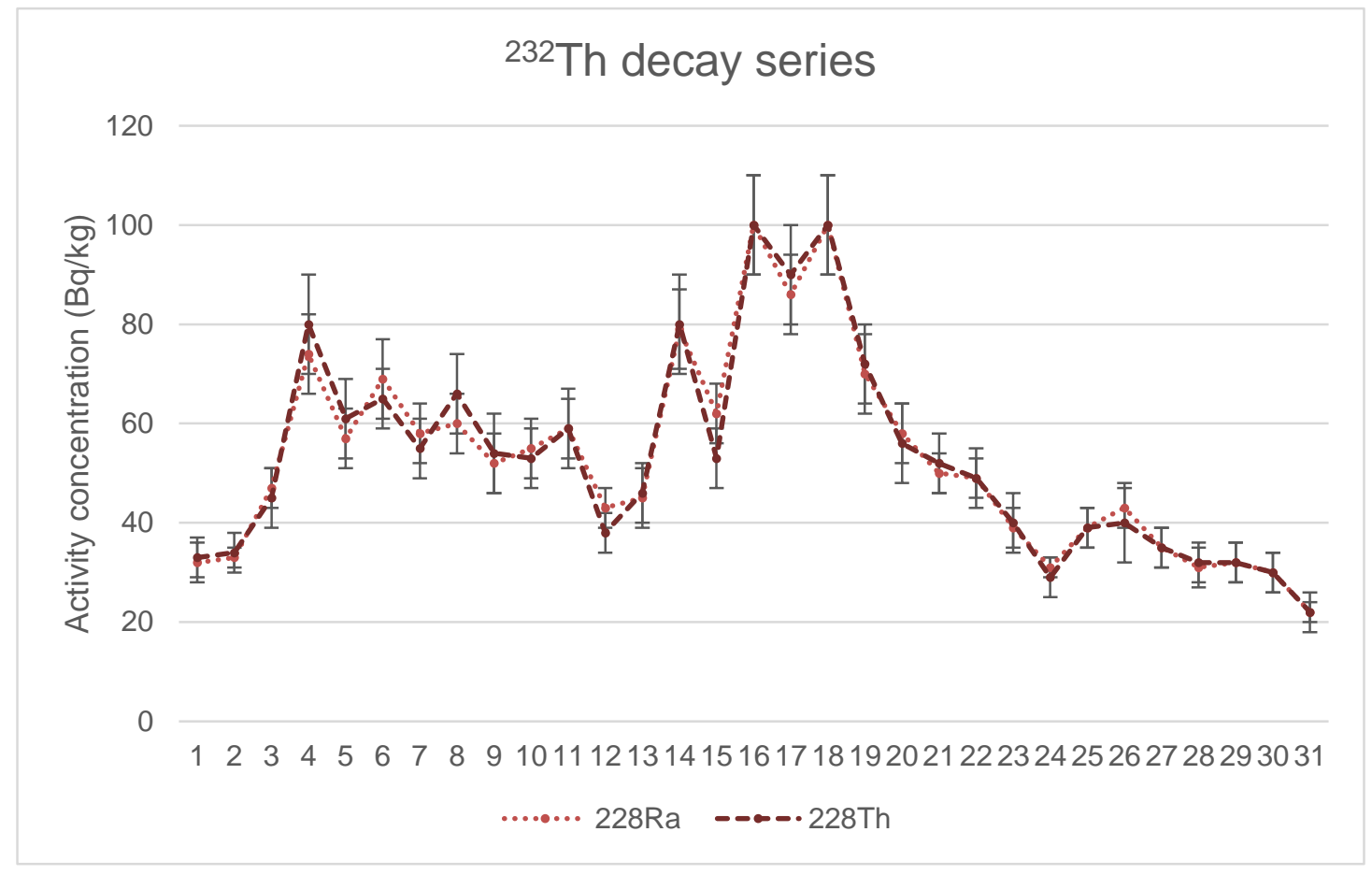

Figure 1: Activity concentration of 31 slag samples for the ${ }^{232} \mathrm{Th}$ decay series (coverage factor, $\mathrm{k}=2$ ). Samples were collected at 31 consecutive days of slag production.

\section{U decay series}

250

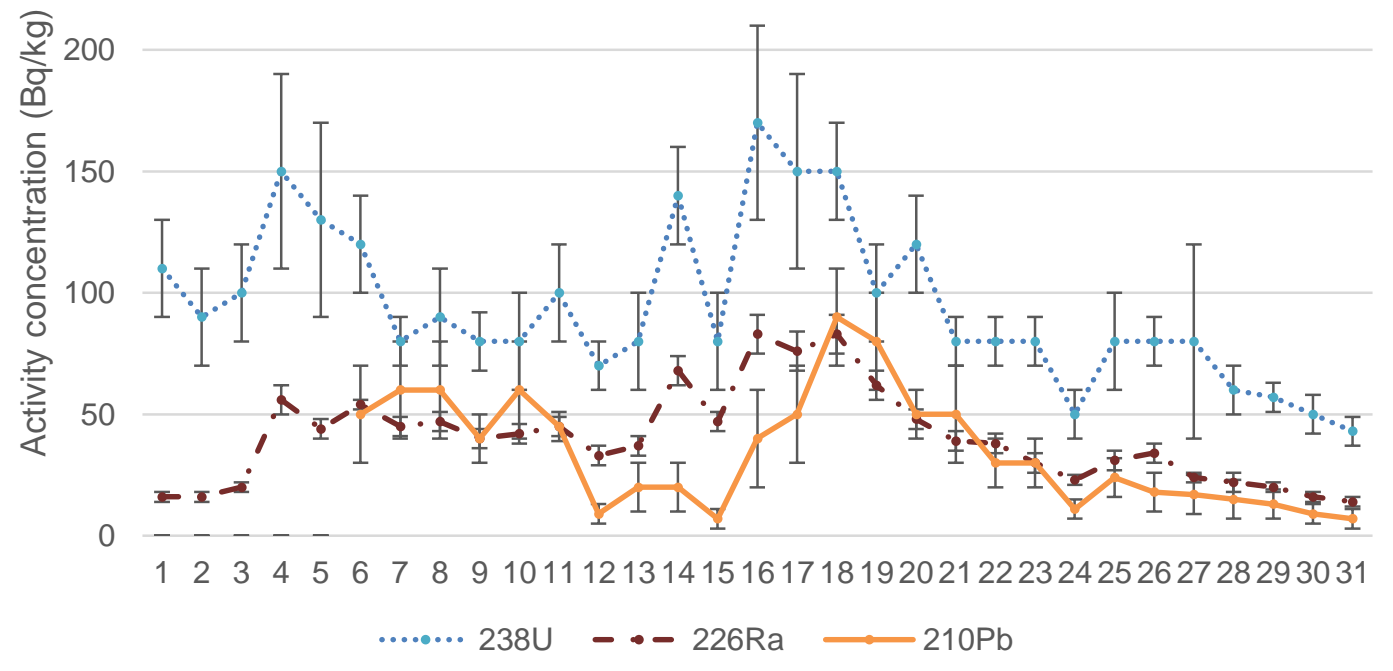

Samples were collected at 31 consecutive days of slag production. 


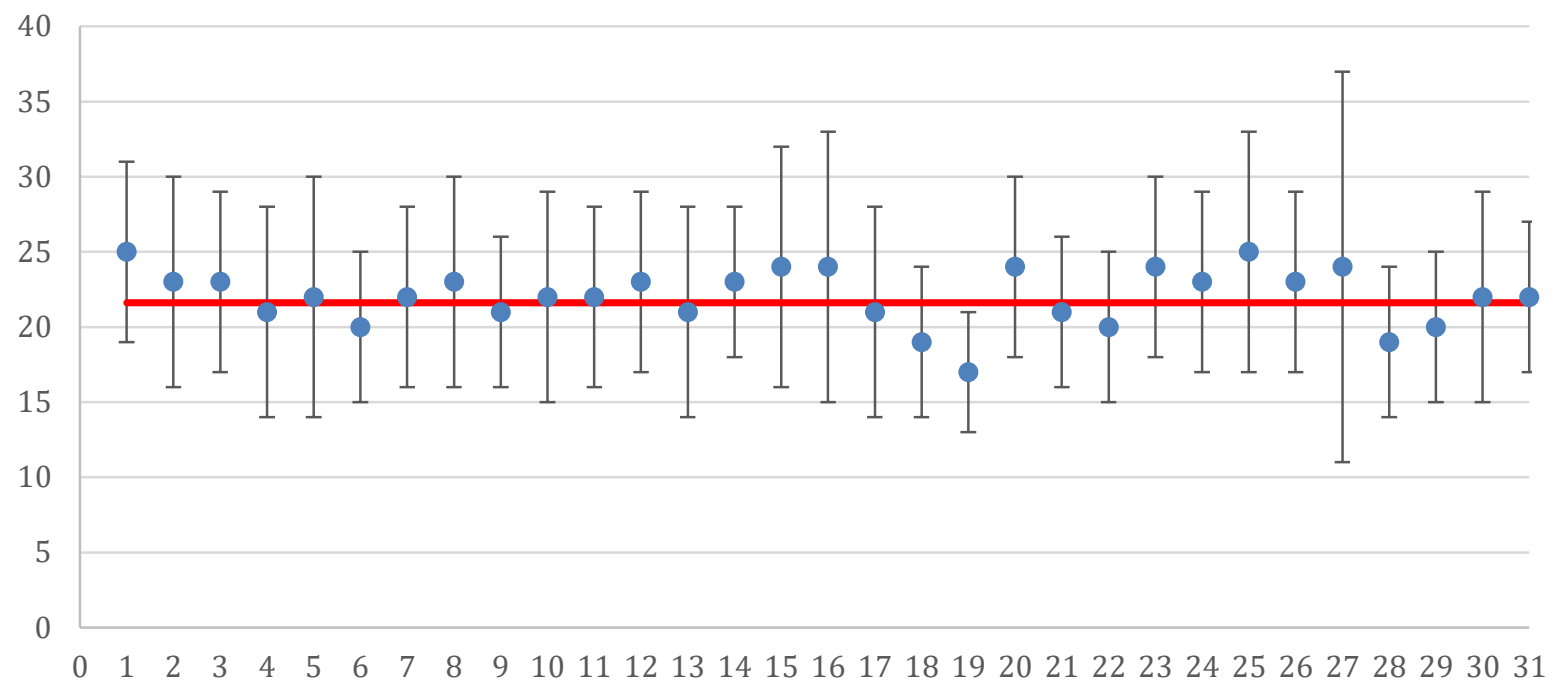

Figure $3:{ }^{238} \mathrm{U} /{ }^{235} \mathrm{U}$ of slag 1 - slag 31 , with ${ }^{238} \mathrm{U}$ via $234 \mathrm{mPa}(\mathrm{k}=2)$. Red line indicates natural uranium

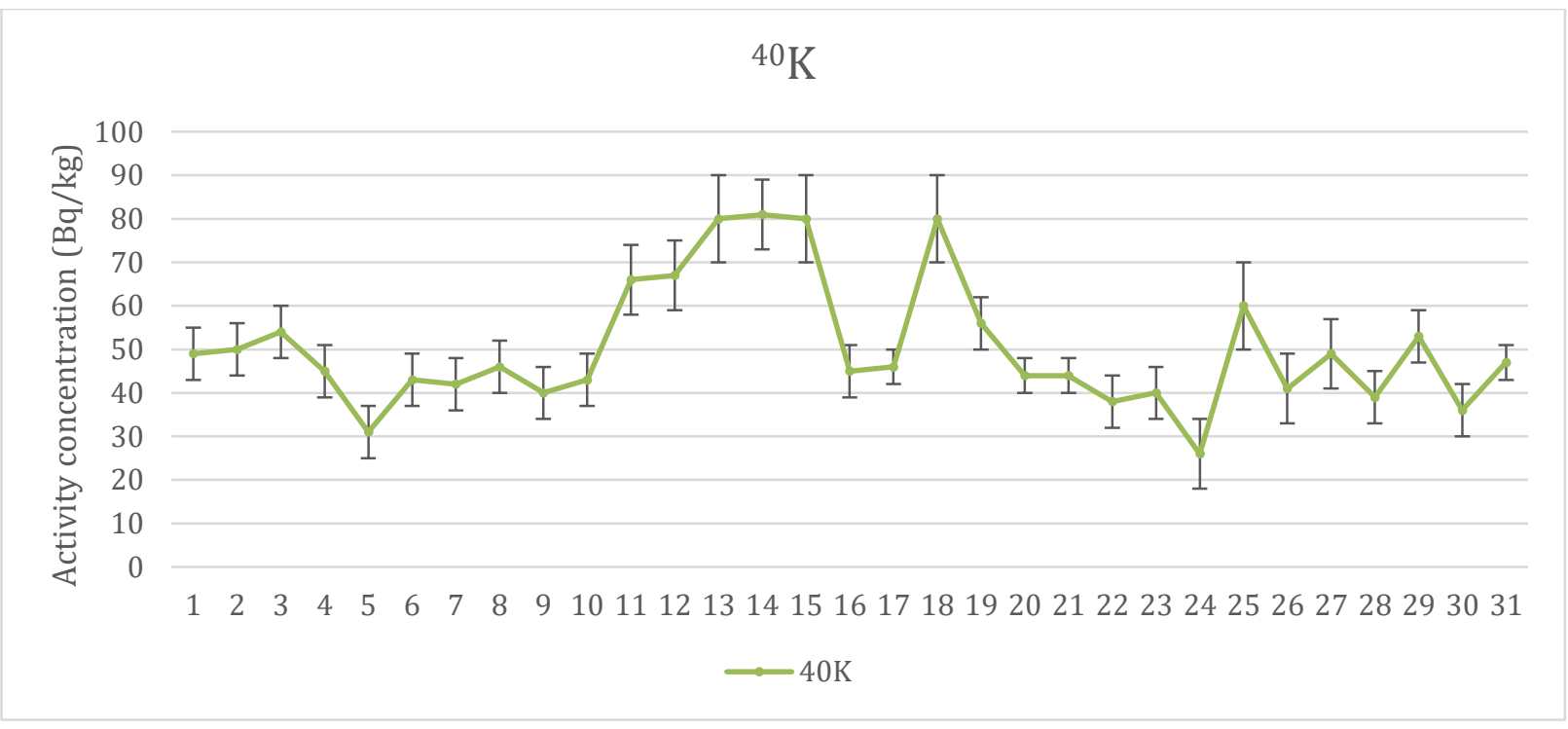
collected at 31 consecutive days of slag production. 


\section{$\mathrm{ACI}$}

1.2

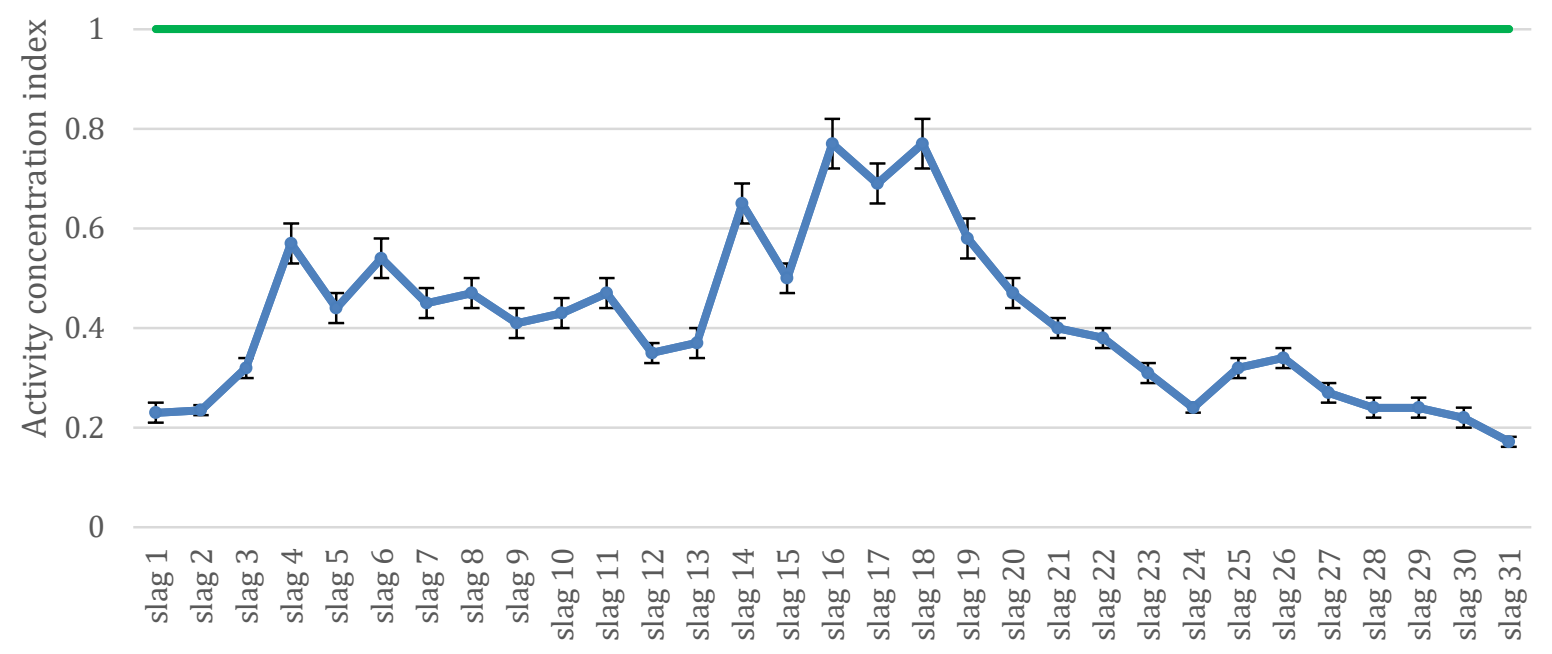

Figure 5: Activity concentration index for slag $1-31(\mathrm{k}=2)$. Samples were collected at 31 consecutive days of slag production.

Tables

Table 1: Overview of the activity concentrations of ${ }^{226} \mathrm{Ra},{ }^{232} \mathrm{Th}$ and ${ }^{40} \mathrm{~K}$ in metallurgical slags in

$\mathrm{Bq} / \mathrm{kg}$. $\mathrm{N}$ is the number of samples.

\begin{tabular}{|c|c|c|c|c|c|c|}
\hline Slag type & $\mathbf{N}$ & ${ }^{226} \mathbf{R a}$ & ${ }^{232} \mathrm{Th}$ & ${ }^{40} \mathrm{~K}$ & Slag origin & Reference \\
\hline Tin slag* & / & 1100 & / & / & Germany & $\begin{array}{l}\text { Leopold and } \\
\text { Weiss, } 2003\end{array}$ \\
\hline Tin slag $\diamond$ & / & / & 11000 & & $\begin{array}{l}\text { United } \\
\text { Kingdom - } \\
\text { The } \\
\text { Netherlands }\end{array}$ & Ryan et al., 2004 \\
\hline Tin slag & / & 2000 & / & / & Malaysia & Omar, 2000 \\
\hline Tin slag & 12 & $492-1153$ & $720-1532$ & $11230-23183$ & Malaysia & Ismail et al., 2011 \\
\hline Tin slag & 4 & / & $12100-14200$ & / & $\begin{array}{l}\text { United } \\
\text { Kingdom }\end{array}$ & $\begin{array}{l}\text { Gilmore and } \\
\text { Jackson, } 1992\end{array}$ \\
\hline Tin slag & 3 & $500-3400$ & $800-7300$ & / & Malaysia & Omar et al., 2008 \\
\hline Tin slag & / & 4570 & 420 & / & Malaysia & Kontol et al., 2007 \\
\hline Tin slag & 3 & $20000-69000$ & $34000-130000$ & / & Brazil & Garcia, 2009 \\
\hline Tin slag & / & 1000 & 4000 & / & $\begin{array}{l}\text { United } \\
\text { Kingdom }\end{array}$ & $\begin{array}{l}\text { European } \\
\text { Commission, } 1997\end{array}$ \\
\hline Tin slag & / & $1000-1200$ & $230-340$ & 330 & Germany & Lehmann, 1996 \\
\hline $\begin{array}{l}\text { Tin melting } \\
\text { slag* }\end{array}$ & / & 5500 & 15000 & / & Germany & $\begin{array}{l}\text { Leopold and } \\
\text { Weiss, } 2003\end{array}$ \\
\hline $\begin{array}{l}\text { Nickel smelt } \\
\text { slag }\end{array}$ & 3 & $16.7-364$ & $7.9-82$ & 78.1 - 888 & Poland & Zak et al., 2008 \\
\hline
\end{tabular}




\begin{tabular}{|c|c|c|c|c|c|c|}
\hline Nickel slag & / & 52 & 78 & 76 & Germany & Lehmann, 1996 \\
\hline Niobium slag & / & / & 80000 & / & / & $\begin{array}{l}\text { European } \\
\text { Commission, } 1997\end{array}$ \\
\hline Niobium slag & / & $3300-5000$ & $17000-118000$ & / & Brazil & $\begin{array}{l}\text { Pires do Rio et al., } \\
2002\end{array}$ \\
\hline Lead slag & / & 270 & 36 & 200 & Germany & Lehmann, 1996 \\
\hline Copper slag* & / & 2000 & / & / & Germany & $\begin{array}{l}\text { Leopold and } \\
\text { Weiss, } 2003\end{array}$ \\
\hline Copper slag & 8 & $287-401$ & $44-73$ & $674-900$ & Poland & Zak, 1995 \\
\hline $\begin{array}{l}\text { Copper } \\
\text { smelt slag• }\end{array}$ & 80 & $236.6-517.8$ & $25.7-183$ & $615.4-1250.6$ & Poland & Zak et al., 2008 \\
\hline Copper slag* & / & 530 & 183 & 1459 & Poland & $\begin{array}{l}\text { Skowronek and } \\
\text { Dulewski, } 2005\end{array}$ \\
\hline Copper slag & 23 & $237-336$ & $26-76$ & $615-1251$ & Poland & Zak et al., 1993 \\
\hline $\begin{array}{l}\text { Copper slag } \\
\text { (old } \\
\text { production) }\end{array}$ & / & $861-2100$ & $18-78$ & $300-730$ & Germany & Lehmann, 1996 \\
\hline $\begin{array}{l}\text { Copper slag } \\
\text { (new } \\
\text { production }\end{array}$ & / & $490-940$ & $41-60$ & $530-760$ & Germany & Lehmann, 1996 \\
\hline $\begin{array}{l}\text { Copper slag } \\
\text { primary } \\
\text { process }\end{array}$ & / & / & 13 & / & / & RP-122 part II \\
\hline $\begin{array}{l}\text { Copper slag } \\
\text { secondary } \\
\text { process }\end{array}$ & / & 17 & 15 & / & / & RP-122 part II \\
\hline Steel slag & / & 88 & 49 & / & $\begin{array}{l}\text { United } \\
\text { Kingdom }\end{array}$ & $\begin{array}{l}\text { Crockett et al., } \\
\text { 2003; Hughes and } \\
\text { Harvey, } 2008\end{array}$ \\
\hline Steel Slag & 1 & 8.62 & 3.73 & 5.14 & Romania & $\begin{array}{l}\text { Ene and Pantelica, } \\
2011\end{array}$ \\
\hline Steel slag & / & / & 150 & / & $\begin{array}{l}\text { The } \\
\text { Netherlands }\end{array}$ & $\begin{array}{l}\text { Van Der Steen, } \\
2004\end{array}$ \\
\hline Steel slag & 1 & 62 & 21 & 51 & China & $\begin{array}{l}\text { Wendling et al., } \\
2013\end{array}$ \\
\hline Steel slag & 3 & $184-213$ & $156-182$ & $<17-25$ & Qatar & Taha et al., 2014 \\
\hline Steel slag & 10 & $15.2-21.4$ & $12.9-15.1$ & $45.3-62.9$ & Croatiä & Sofilic et al., 2011 \\
\hline Steel slag & / & $5-31$ & $0-5$ & / & / & RP-122 part II \\
\hline Steel slag & / & $100-600$ & / & / & Slovenia & Smodis et al., 2006 \\
\hline $\begin{array}{l}\text { Steel and } \\
\text { Iron slag }\end{array}$ & / & 150 & 150 & / & / & $\begin{array}{l}\text { European } \\
\text { Commission, } 1997\end{array}$ \\
\hline
\end{tabular}




\begin{tabular}{|c|c|c|c|c|c|c|}
\hline Steel slag $\square$ & / & 196 & 29.6 & 148 & Romania & $\begin{array}{l}\text { Tanase and } \\
\text { Tanase, } 2003\end{array}$ \\
\hline Steel slag & 5 & $51-114$ & $28.6-35.5$ & $118-145$ & Romania & $\begin{array}{l}\text { Sahagia et al., } \\
2014\end{array}$ \\
\hline $\begin{array}{l}\text { Non-Iron } \\
\text { slag }\end{array}$ & / & $20-30$ & $10-15$ & 20 & South Korea & Jeong et al., 2014 \\
\hline Iron slag & 2 & $107.4-113.9$ & $95.2-109.6$ & $2.27-18.9$ & Saudi Arabia & $\begin{array}{l}\text { Alamoudi and } \\
\text { Almehmadi, } 2013\end{array}$ \\
\hline Iron slag & / & $10-220$ & $10-90$ & $10-150$ & South Korea & Jeong et al., 2014 \\
\hline Iron slag & 12 & $15-22$ & / & / & Scandinavia & Broden et al., 2001 \\
\hline Iron slag & / & $64-380$ & $30-98$ & / & / & RP-122 part II \\
\hline Iron slag & 6 & $4-234$ & $2-196$ & $8-105$ & Slovenia & $\begin{array}{l}\text { NORM4Building } \\
\text { database, } 2016\end{array}$ \\
\hline EAF slag & 3 & $14.6-17.1$ & $6.7-13.1$ & $15.3-36.9$ & Croatiä & Sofilic et al., 2010 \\
\hline EAF slag & 12 & $18.3-21.6$ & $12.3-15.4$ & $45.3-63.8$ & Croatia & Sofilic et al., 2010 \\
\hline EAF slag & / & 25 & 5 & 10 & Greece & $\begin{array}{l}\text { Xirouchakis and } \\
\text { Manolakou, } 2011\end{array}$ \\
\hline $\begin{array}{l}\text { Blast furnace } \\
\text { slag }\end{array}$ & / & $160-165$ & $35-40$ & / & Belgium & $\begin{array}{l}\text { Vanmarcke et al., } \\
2010\end{array}$ \\
\hline $\begin{array}{l}\text { Blast furnace } \\
\text { slag }\end{array}$ & 40 & $13.7-310.1$ & $3.8-330$ & $18.1-290.1$ & Turkey & Ugur et al., 2013 \\
\hline $\begin{array}{l}\text { Blast furnace } \\
\text { slag }\end{array}$ & 1 & 166 & 47.6 & 232.3 & Spain & $\begin{array}{l}\text { Chinchon-Paya et } \\
\text { al., } 2011\end{array}$ \\
\hline $\begin{array}{l}\text { Blast furnace } \\
\text { (boiler) slag }\end{array}$ & 368 & $12.4-351.1$ & $2.2-115$ & $18.0-1400$ & Poland & Zak et al., 2008 \\
\hline $\begin{array}{l}\text { Blast furnace } \\
\text { slag }\end{array}$ & 4 & $116-223$ & $83-141$ & $136-196$ & China & $\begin{array}{l}\text { Wendling et al., } \\
2013\end{array}$ \\
\hline $\begin{array}{l}\text { Blast furnace } \\
\text { slag }\end{array}$ & 12 & $8-308$ & $1.6-337.3$ & $18.4-388.9$ & Turkey & Turhan, 2008 \\
\hline $\begin{array}{l}\text { Blast furnace } \\
\text { slag }\end{array}$ & / & 251.2 & 24.8 & 361.7 & Croatia & Sofilic et al,. 2011 \\
\hline $\begin{array}{l}\text { Blast furnace } \\
\text { slag }\end{array}$ & 2 & $143.4-150.9$ & $45.6-45.8$ & $75.7-76.8$ & / & $\begin{array}{l}\text { Puertas et al., } \\
2015\end{array}$ \\
\hline $\begin{array}{l}\text { Blast furnace } \\
\text { slag }\end{array}$ & 5 & $105-129$ & $32.4-102$ & $97.2-209$ & Finland & Mustonen, 1984 \\
\hline $\begin{array}{l}\text { Blast furnace } \\
\text { slag }\end{array}$ & 5 & $323 \pm 18.6$ & $39.8 \pm 7.2$ & $158 \pm 16$ & Egypt & Sharaf et al., 1999 \\
\hline $\begin{array}{l}\text { Blast furnace } \\
\text { slag }\end{array}$ & / & $88.3-142.0$ & $26.8-46.0$ & $188-269$ & Hungary & $\begin{array}{l}\text { Gallyas and Torok, } \\
1984\end{array}$ \\
\hline $\begin{array}{l}\text { Blast furnace } \\
\text { slag }\end{array}$ & / & $186.69 \pm 2.38$ & $35.87 \pm 1.67$ & $295.91 \pm 9.08$ & Turkey & Baltas et al., 2014 \\
\hline
\end{tabular}




\begin{tabular}{|c|c|c|c|c|c|c|c|}
\hline & $\begin{array}{l}\text { Blast furnace } \\
\text { slag† }\end{array}$ & 42 & $18.5-458.8$ & 22 & $25.7-2227.4$ & Poland & Pensko et al., 1980 \\
\hline & $\begin{array}{l}\text { Blast furnace } \\
\text { slag* }\end{array}$ & / & 2100 & 340 & 1000 & / & RP-112 \\
\hline & $\begin{array}{l}\text { Blast furnace } \\
\text { slag } \diamond\end{array}$ & / & 270 & 70 & 240 & / & RP-112 \\
\hline & $\begin{array}{l}\text { Blast furnace } \\
\text { slag }\end{array}$ & / & $131-139$ & 4 & $157-177$ & Ukraine & $\begin{array}{l}\text { NORM4Building } \\
\text { database, } 2016\end{array}$ \\
\hline & $\begin{array}{l}\text { Metallurgical } \\
\text { slag }\end{array}$ & / & 251 & 115 & 1400 & Poland & $\begin{array}{l}\text { Skowronek and } \\
\text { Dulewski, } 2005\end{array}$ \\
\hline & $\begin{array}{l}\text { Metallurgical } \\
\text { slag }\end{array}$ & 6 & $41-124$ & $41-106$ & $166-395$ & Slovakia & Cabanekova, 1996 \\
\hline & $\begin{array}{l}\text { Metallurgical } \\
\text { slag }\end{array}$ & 2 & $162-173$ & $25-52$ & $179-219$ & Romania & $\begin{array}{l}\text { Muntean et al., } \\
2014\end{array}$ \\
\hline & $\begin{array}{l}\text { Metallurgical } \\
\text { slag }\end{array}$ & 40 & $13-341$ & $2-115$ & $36-889$ & Poland & Zak, 1995 \\
\hline & $\begin{array}{l}\text { Metallurgical } \\
\text { slag }\end{array}$ & 8 & $10.8-38.8$ & $2.7-21.8$ & $7.3-63.3$ & / & Sofilic et al., 2004 \\
\hline & $\begin{array}{l}\text { Metallurgical } \\
\text { slag }\end{array}$ & 160 & $33-351$ & $12-102$ & $14-825$ & Poland & Zak et al., 1993 \\
\hline & $\begin{array}{l}\text { Metallurgical } \\
\text { slag + dross } \\
\neq\end{array}$ & 43 & $10.0-436.0$ & $9.5-55.6$ & $75.7-649.6$ & & Cabanekova, 2008 \\
\hline 760 & Mentioned as $\mathrm{n}$ & laximu & value & & & & \\
\hline 761 & Mentioned as $\mathrm{t}$ & ypical & & & & & \\
\hline 762 & Mentioned as a & verage & lue & & & & \\
\hline 763 & Could contain & ample & eported by Zak & et al. 1993 and Zak 1995 & & & \\
\hline 764 & Could contain $\mathrm{k}$ & oiler s & data and is con & verted from $\mathrm{pCi} / \mathrm{g}$ & & & \\
\hline 765 & Could contain c & louble & ith Cabanekova & 1996 & & & \\
\hline 766 & & & & & & & \\
\hline 767 & Table 2: Exempti & on/cle & nce levels repo & rted in EU-BSS IAEA (e & (equilibrium $\mathrm{s}$ & ration) anc & \\
\hline 768 & 22 part II (dise & uilibr & ( situation) & & & & \\
\hline & & & SS $\mid$ IAEA* & RP-122 part II & & & \\
\hline & Radionuclide & $\begin{array}{r}\text { Exem } \\
1\end{array}$ & $\begin{array}{l}\text { ion/clearance } \\
\text { l(Bq/kg) }\end{array}$ & $\begin{array}{c}\text { Exemption/clearance } \\
\text { level (Bq/kg) }\end{array}$ & & & \\
\hline & ${ }^{238} \mathrm{U}$ & & 1000 & 5000 & & & \\
\hline & ${ }^{226} \mathbf{R a}$ & & 1000 & $500^{* *}$ & & & \\
\hline & ${ }^{210} \mathrm{~Pb}$ & & 1000 & $5000^{* *}$ & & & \\
\hline & ${ }^{228} \mathbf{R a}$ & & 1000 & $5000^{* *}$ & & & \\
\hline & ${ }^{228} \mathrm{Th}$ & & 1000 & $500^{* *}$ & & & \\
\hline & $235 \mathrm{U}$ & & 1000 & $1000^{* *}$ & & & \\
\hline
\end{tabular}




\begin{tabular}{|l|l|l|}
${ }^{40} \mathbf{K}$ & 10000 & 5000 \\
\hline
\end{tabular}

* The activity concentration criterion of the EU-BSS | IAEA assumes equilibrium (European Council, 2014; IAEA, 2004).

** To indicate that the derived clearance level also includes daughter nuclides (European Commission, 2002).

Table 3: HPGe detectors used for gamma-ray analysis.

\begin{tabular}{|c|c|c|c|c|c|}
\hline & Ge-3 & Ge-4 & Ge-5 & Ge-8 & Ge-T5 \\
\hline Crystal type & P-type, coaxial & $\begin{array}{l}\text { P-type, } \\
\text { coaxial }\end{array}$ & P-type, planar & P-type, planar & $\begin{array}{l}\text { P-type, } \\
\text { coaxial }\end{array}$ \\
\hline Relative efficiency & $60 \%$ & $100 \%$ & $50 \%$ & $19 \%$ & $46 \%$ \\
\hline Shielding & $\begin{array}{c}10 \mathrm{~cm} \text { copper }+14 \\
\mathrm{~cm} \text { lead }\end{array}$ & $\begin{array}{l}7.5 \mathrm{~cm} \text { copper } \\
+15 \mathrm{~cm} \text { lead }\end{array}$ & $\begin{array}{c}5 \mathrm{~cm} \text { copper }+ \\
15 \mathrm{~cm} \text { lead }\end{array}$ & $\begin{array}{l}5 \mathrm{~cm} \text { copper } \\
+15 \mathrm{~cm} \text { lead }\end{array}$ & $\begin{array}{c}1 \mathrm{~mm} \\
\text { copper+ } 10 \\
\mathrm{~cm} \text { lead }\end{array}$ \\
\hline Top dead layer & $0.7 \mathrm{~mm}$ & $0.5 \mu \mathrm{m}$ & $0.5 \mu \mathrm{m}$ & $0.5 \mu \mathrm{m}$ & $0.6 \mathrm{~mm}$ \\
\hline Samples measured & $\begin{array}{l}\text { Slag 5, Flue dust } \\
\text { samples }\end{array}$ & $\begin{array}{c}\text { Slag } 4,6,9 \text {, } \\
11,14,20,22, \\
26,29,31\end{array}$ & $\begin{array}{c}\text { Slag } 1,2,3,7, \\
12,15,17,18 \\
19,21,23 \\
27,30\end{array}$ & $\begin{array}{l}\text { Slag } 8,10,13 \text {, } \\
16,24,25,28\end{array}$ & $\begin{array}{c}\text { Feedstock } \\
\text { materials }\end{array}$ \\
\hline FWHM of QA at 661.6 & 1.55 & 1.57 & 1.31 & 1.23 & 1.41 \\
\hline FWHM of QA at 1332 & 1.89 & 1.96 & 1.75 & 1.64 & 1.86 \\
\hline
\end{tabular}

Table 4: minimum and maximum activity concentrations, ratio of the maximum over the minimum activity concentration and ratio of different long living radionuclides over each other for feedstock material, flue dust and non-ferrous fayalite slag samples $(\mathrm{k}=2)$.

\begin{tabular}{|c|c|c|c|c|c|c|}
\hline \multirow{3}{*}{ Radionuclide } & \multicolumn{3}{|c|}{ Feedstock material (5 samples) } & \multicolumn{3}{|c|}{ Flue dust (9 samples) } \\
\hline & \multicolumn{2}{|c|}{$\begin{array}{c}\text { Activity concentration } \\
(\mathrm{Bq} / \mathrm{kg})\end{array}$} & \multirow[b]{2}{*}{$\begin{array}{c}\text { Ratio } \\
\max / \min \end{array}$} & \multicolumn{2}{|c|}{$\begin{array}{c}\text { Activity concentration } \\
(\mathrm{Bq} / \mathrm{kg})\end{array}$} & \multirow[b]{2}{*}{$\begin{array}{c}\text { Ratio } \\
\max / \mathbf{m i n}\end{array}$} \\
\hline & $\min$ & $\max$ & & $\min$ & $\max$ & \\
\hline $238 \mathrm{U}$ & $770 \pm 90$ & $2100 \pm 300$ & $2.7 \pm 0.5$ & $21 \pm 8$ & $50 \pm 10$ & $2 \pm 1$ \\
\hline${ }^{226} \mathbf{R a}$ & $410 \pm 40$ & $1600 \pm 200$ & $3.9 \pm 0.6$ & $0.8 \pm 0.2$ & $3.3 \pm 0.2$ & $4 \pm 1$ \\
\hline${ }^{210} \mathrm{~Pb}$ & $6000 \pm 2000$ & $22000 \pm 7000$ & $4 \pm 2$ & $300 \pm 200$ & $900 \pm 300$ & $3 \pm 2$ \\
\hline${ }^{228} \mathbf{R a}$ & $770 \pm 70$ & $2100 \pm 200$ & $2.7 \pm 0.4$ & $1.4 \pm 0.2$ & $2.8 \pm 0.2$ & $2.0 \pm 0.3$ \\
\hline${ }^{235} \mathbf{U}$ & $27 \pm 4$ & $74 \pm 8$ & $2.7 \pm 0.5$ & $0.8 \pm 0.2$ & $2.3 \pm 0.2$ & $2.9 \pm 0.8$ \\
\hline${ }^{228} \mathrm{Th}$ & $800 \pm 100$ & $2000 \pm 400$ & $2.2 \pm 0.6$ & $1.2 \pm 0.2$ & $3 \pm 2$ & $3 \pm 2$ \\
\hline${ }^{40} \mathrm{~K}$ & $10 \pm 8$ & $90 \pm 10$ & $9 \pm 7$ & $49 \pm 6$ & $210 \pm 20$ & $4.3 \pm 0.7$ \\
\hline${ }^{228} \mathrm{Ra} /{ }^{228} \mathrm{Th}$ & $0.9 \pm 0.2$ & $1.0 \pm 0.2$ & & $0.96 \pm 0.09$ & $1.5 \pm 0.4$ & \\
\hline${ }^{238} \mathrm{U} /{ }^{226} \mathrm{Ra}$ & $1.2 \pm 0.2$ & $1.9 \pm 0.3$ & & $10 \pm 3$ & $30 \pm 10$ & \\
\hline${ }^{210} \mathrm{~Pb} /{ }^{226} \mathrm{Ra}$ & $8 \pm 3$ & $20 \pm 7$ & & $110 \pm 30$ & $900 \pm 300$ & \\
\hline
\end{tabular}

\begin{tabular}{|c|c|c|}
\hline \multirow{4}{*}{ Radionuclide } & \multicolumn{3}{|c|}{ Non-ferrous fayalite slag (31 samples) } \\
\cline { 2 - 3 } & \multicolumn{2}{|c|}{$\begin{array}{c}\text { Activity concentration } \\
\text { (Bq/kg) }\end{array}$} \\
\cline { 2 - 4 } & $\min \max$ & $\begin{array}{c}\text { Ratio } \\
\mathrm{max} / \mathrm{min}\end{array}$ \\
\hline
\end{tabular}




\begin{tabular}{|c|c|c|c|}
${ }^{238} \mathbf{U}$ & $42 \pm 4$ & $180 \pm 40$ & $4 \pm 1$ \\
${ }^{226} \mathbf{R a}$ & $14 \pm 2$ & $83 \pm 8$ & $6 \pm 1$ \\
${ }^{210} \mathbf{P b}$ & $7 \pm 4$ & $90 \pm 20$ & $13 \pm 7$ \\
${ }^{228} \mathbf{R a}$ & $22 \pm 2$ & $100 \pm 10$ & $4.5 \pm 0.6$ \\
${ }^{235} \mathbf{U}$ & $2.0 \pm 0.4$ & $8 \pm 2$ & $4 \pm 1$ \\
${ }^{228} \mathbf{T h}$ & $21 \pm 2$ & $100 \pm 10$ & $4.7 \pm 0.7$ \\
${ }^{40} \mathbf{K}$ & $26 \pm 8$ & $80 \pm 10$ & $3.1 \pm 0.5$ \\
\hline${ }^{228} \mathbf{R a} /{ }^{228} \mathbf{T h}$ & $0.9 \pm 0.2$ & $1.1 \pm 0.2$ & \\
${ }^{238} \mathbf{U} /{ }^{226} \mathbf{R a}$ & $1.7 \pm 0.4$ & $7 \pm 2$ & \\
${ }^{210} \mathbf{P b} /{ }^{226} \mathbf{R a}$ & $0.14 \pm 0.09$ & $1.4 \pm 0.5$ & \\
\hline
\end{tabular}

780 